4 Hansen $\mathrm{O}$, Pedersen S. Optimal inhalation technique with terbutaline Turbuhaler. Eur f Respir Dis 1989;2:637-9.

5 Pedersen S, Hansen OR, Fuglsang G. Influence of inspiratory flow rate upon the effect of a Turbuhaler. Arch Dis Child 1990;65:308-19.

6 Engel T, Scharling B, Skovsted B, Heinig JH. Effects, side effects and plasma concentrations of terbutaline in adult asthmatics after inhaling from a dry powder inhaler device asthmatics after inhaling from a dry powder inhaler device at different inhalations and

7 Newman SP, Hollingworth A, Clark AR. Effect of different modes of inhalation on drug delivery from a dry powder inhaler. Int $\mathcal{F}$ Pharm 1994;102:127-32.

8 Borgstrom L, Bondesson E, Moren F, Newman SP. Lung deposition of budesonide inhaled via Turbuhaler. A com- parison with terbutaline sulphate. Eur Respir $\mathcal{F}$ 1994;7: 69-73.

9 Borgstrom L, Newman SP, Weisz A, Moren F. Pulmonary deposition of inhaled terbutaline: comparison of scanning gamma camera and urinary excretion methods. 7 Pharm Sci 1992;81:753-5.

10 Jaegfeld $\mathrm{H}$, Andersoon JAR, Trofast E, Wetterlin KIL. Particle size distribution from different modifications of Turbuhaler. In: Newman SP, Moren F, Crompton GK, eds. A new concept in inhalation therapy.

11 O'Callaghan C, Lynch J, Robertson C. Improvement in sodium cromoglycate delivery from a spacer device by use of an antistatic lining, immediate inhalation, and avoiding multiple actuations of drug. Thorax 1993;48:603-6.

\title{
Radiographic features of staphylococcal pneumonia in adults and children
}

\author{
John Macfarlane, Donald Rose
}

\begin{abstract}
Background - Clinical and laboratory features do not accurately correlate with the cause of community acquired pneumonia. A study was performed to examine whether the radiographic features of staphylococcal pneumonia are sufficiently distinct to aid early diagnosis.

Methods - The chest radiographs of 34 patients (including eight children) with proven staphylococcal pneumonia were reviewed by two experienced observers using methods described previously. Features on presentation and follow up were noted.

Results - The most striking features were the presence of multilobar consolidation on presentation, cavitation, pneumatocoeles and spontaneous pneumothorax, together with a tendency to radiographic deterioration after admission in both adults and children. Some of these features are much less common with other causes of community acquired pneumonia. However, most of the cases did not have these classic features.

Conclusions - The presence of certain radiographic features, including multilobar shadowing, cavitation, pneumatocoeles, and spontaneous pneumothorax, are seen with staphylococcal pneumonia in adults and children, but their absence does not exclude the diagnosis.

(Thorax 1996;51:539-540)
\end{abstract}

Keywords: staphylococcal pneumonia, radiographic changes, adults, children, diagnosis.

Staphylococcal pneumonia is an uncommon but serious infection which accounts for about $1 \%$ of community acquired pneumonias. ${ }^{1}$ The clinical and laboratory features of different forms of community acquired infection have been shown not to be an accurate predictor of aetiology. ${ }^{2}$ Staphylococcal pneumonia is said to have characteristic radiographic features ${ }^{34}$ and, as such, these may assist early clinical identification of staphylococcal infection to allow appropriate antibiotic therapy. However, no studies have been made of the radiographic appearances of staphylococcal pneumonia since effective antibiotics became widely available which may act to modify the radiographic picture of the infection. We have previously reported on the clinical and laboratory features of 61 cases of community acquired staphylococcal pneumonia in adults ${ }^{5}$ and report here the radiographic findings of 34 patients, including eight children, with proven staphylococcal pneumonia.

\section{Methods}

Cases of community acquired staphylococcal pneumonia were identified from admission diagnosis records of the Trent Region and chest radiographs of 34 patients were available for study. As in our previous clinical study, ${ }^{5}$ the diagnosis was accepted if Staphylococcus aureus was isolated as a heavy growth from sputum, tracheal aspirate or from blood, pleural fluid, or necropsy lung tissue.

Available chest radiographs were reviewed by two experienced observers. Lateral views were available in many cases but infrequently provided extra information. Shadowing was recorded as mainly homogeneous or mainly patchy. Other features including pleural fluid, lobar or segmental collapse (loss of volume), cavitation and pneumatocoeles were noted. A pneumatocoele was differentiated from cavitation or abscess formation by the presence of a smooth and thin walled cystic structure, sometimes with a fluid level. A swollen lobe was recognised by an increase in the volume of the lobe, together with a displaced convex fissure. 
Table 1 Details of 34 cases of staphylococcal pneumonia including radiographic features

\begin{tabular}{|c|c|c|c|}
\hline & $\begin{array}{l}\text { Total } \\
(n=34)\end{array}$ & $\begin{array}{l}\text { Adults } \\
(n=26)\end{array}$ & $\begin{array}{l}\text { Children } \\
(n=8)\end{array}$ \\
\hline Median (range) (years) & - & $49(24-76)$ & $\begin{array}{l}1 \text { (1 month } \\
-8 \text { years })\end{array}$ \\
\hline $\begin{array}{l}M: F \\
\text { No. of deaths }\end{array}$ & $\begin{array}{l}16: 18 \\
9\end{array}$ & $\begin{array}{l}15: 11 \\
9\end{array}$ & $\begin{array}{l}1: 7 \\
0\end{array}$ \\
\hline $\begin{array}{l}\text { Radiographic features on } \\
\text { presentation } \\
\text { Homogeneous shadowing } \\
\text { Patchy shadowing } \\
\text { Mixed picture } \\
\text { Swollen lobe } \\
\text { Single lobe involvement } \\
\text { Multilobe involvement } \\
\text { Bilateral involvement }\end{array}$ & $\begin{array}{r}20 \\
11 \\
3 \\
5 \\
14 \\
20 \\
12\end{array}$ & $\begin{array}{r}14 \\
10 \\
2 \\
3 \\
12 \\
14 \\
9\end{array}$ & $\begin{array}{l}6 \\
1 \\
1 \\
2 \\
2 \\
6 \\
3\end{array}$ \\
\hline $\begin{array}{l}\text { Associated features } \\
\text { Pleural effusion } \\
\text { Lobar/segmental collapse } \\
\text { Cavitation } \\
\text { Pneumatocoeles } \\
\text { Spontaneous } \\
\text { pneumothorax } \\
\text { Deterioration after } \\
\text { hospital admission } \\
\text { Spread to opposite lung }\end{array}$ & $\begin{array}{c}11 \\
6 \\
9 \\
7 \\
7 \\
20 / 31^{*} \\
6\end{array}$ & $\begin{array}{l}7 \\
5 \\
7 \\
4 \\
3 \\
15 / 24 \\
4\end{array}$ & $\begin{array}{l}4 \\
1 \\
2 \\
3 \\
4 \\
5 / 7 \\
2\end{array}$ \\
\hline
\end{tabular}

* No follow up film on three patients.

Table 2 Comparison of radiographic findings in adult staphylococcal pneumonia with adapted data previously reported for causes of community acquired pneumonia ${ }^{8}$ expressed as percentages

\begin{tabular}{|c|c|c|c|c|}
\hline & $\begin{array}{l}\text { Staphylococcal } \\
(n=26)\end{array}$ & $\begin{array}{l}\text { Pneumococcal } \\
(n=91)\end{array}$ & $\begin{array}{l}\text { Legionella } \\
(n=49)\end{array}$ & $\begin{array}{l}\text { Mycoplasma } \\
(n=46)\end{array}$ \\
\hline $\begin{array}{l}\text { Mainly homogeneous shadowing } \\
\text { Multilobe involvement on }\end{array}$ & 60 & 74 & 82 & 50 \\
\hline $\begin{array}{l}\text { presentation } \\
\text { Radiographic deterioration after }\end{array}$ & 59 & 39 & 39 & 52 \\
\hline hospital admission & 64 & 32 & 65 & 25 \\
\hline $\begin{array}{l}\text { Associated features } \\
\text { Pleural effusion } \\
\text { Cavitation } \\
\text { Lobar/segmental collapse }\end{array}$ & $\begin{array}{l}32 \\
26 \\
18\end{array}$ & $\begin{array}{r}34 \\
4 \\
25\end{array}$ & $\begin{array}{r}24 \\
2 \\
37\end{array}$ & $\begin{array}{r}20 \\
0 \\
26\end{array}$ \\
\hline
\end{tabular}

\section{Results}

The details of the cases studied and the chest radiographic findings are shown in table 1. Homogeneous shadowing occurred more frequently than patchy shadowing in both children and adults, with consolidation being present in more than one lobe at presentation in $75 \%$ of the children and just over half of the adults. Cavitation or abscess formation was noted in seven of the 26 adults, of whom five had multiple cavities. Pneumatocoeles were seen in three of the eight children and in four of the adults. Half of the children developed a spontaneous pneumothorax, in two cases associated with a pleural effusion or empyema. Two of the three adults who developed a pneumothorax had associated pleural effusions or an empyema.

\section{Discussion}

The most striking features noted were the presence of multilobar consolidation on presentation, cavitation, and spontaneous pneumothorax, together with a tendency to radiographic deterioration after admission. Such features have been well described in childhood staphylococcal pneumonia before ${ }^{6}$ but also seem to occur in adults. Pneumatocoeles were seen in $41 \%$ of cases, pneumothorax in $20 \%$, pleural effusions in one third, and bilateral shadowing in $35 \%$. Although pleural effusions and progressive lung shadowing are said to be a feature of staphylococcal pneumonia, pneumatocoeles and pneumothorax are said to be uncommon ${ }^{4}$ and an observation of pneumatocoeles in an adult has warranted a case report. ${ }^{7}$ Our study shows that, although less common than in children, such features do occur in adults with staphylococcal pneumonia and, if present, they may be a useful clinical pointer to staphylococcal infection. It is possible that radiographic changes may be modified by effective antistaphylococcal antibiotics. Such agents were less available when previous reviews were published over three decades ago. ${ }^{34}$ We do not have the data to assess whether antibiotics given before admission might also have influenced the radiographic appearances seen in our series.

To assess the comparative radiographic features of staphylococcal pneumonia with those of other causes of community acquired pneumonia our results are compared with those from previous radiographic studies of community acquired pneumonia using similar methods and the same observers (table 2). ${ }^{8}$ Staphylococcal pneumonia shares some of the features of other bacterial pneumonias caused by Legionella pneumophila and Streptococcus pneumoniae apart from the presence of cavitation in a quarter of cases. Swollen lobes, said to be a characteristic feature of Klebsiella pneumonia, were seen in $12 \%$ of our cases and also occur occasionally with other causes of community acquired pneumonia. The swollen lobe probably represents only an intense inflammatory exudative response to a severe infection.

In conclusion, bilateral patchy shadowing, together with cavitation, pneumatocoeles, and spontaneous pneumothorax, were features of staphylococcal pneumonia in both adults and children and their presence may act as a pointer towards staphylococcal aetiology when compared with other causes of bacterial community acquired pneumonia. However, the absence of these findings does not exclude staphylococcal infection as most cases did not have these classic features.

We are grateful to Dr Mark Woodhead for his help in identifying the original cases in the Trent Region, to Dr Heidi Doughty
for organising the radiographs, and to Mrs Rosamund Macfor organising the radiographs, and to Mrs Rosamund Mac-
farlane and Mrs Hilary Hughes for help with preparing the farlane and

1 Macfarlane J. An overview of community acquired pneumonia with lessons learned from the British Thoracic Society Study. Semin Respir Infect 1994;9:153-65.

2 Woodhead MA, Macfarlane JT. Comparative clinical and laboratory features of legionella with pneumococcal and mycoplasma pneumonias. Br f Dis Chest 1987;81:

mycoplasma pneumonias. Br f Dis Chest 1987;81:133-9. Staphylococcal pneumonia. A review of 21 cases in adults. Staphylococcal pneumonia. A re
$N$ Engl f Med 1958;258:919-28.

4 Wiita RM, Cartwright RR, Davis JG. Staphylococcal pneumonia in adults. A review of 102 cases. Am $\mathcal{F}$ Roentgenol 1961:86:1083-91.

5 Woodhead MA, Radvan J, Macfarlane JT. Adult communityacquired staphylococcal pneumonia in the antibiotic era: review of 61 cases. $Q 7 M$ Med 1987;64:783-90.

6 Chartrand SA, McCracken GH. Staphylococcal pneumoni in infants and children. Pediatr Infect Dis 1982;1:19-23.

7 Olutola PS, Komolafe F, Onile BA. Multiple staphylococca pneumatocoeles in an adult. Diagn Imag Clin Med 1984, 53:306-9.

8 Macfarlane JT, Miller AC, Roderick Smith WH, Morris AH, Rose DH. Comparative radiographic features of community acquired legionnaires' disease, pneumococcal pneumonia, mycoplasma pneumonia, and psittacosis. Thorax 1984;39:28-33. 